\title{
Does human capital moderate the relationship between strategic thinking and strategic human resource management?
}

\author{
Ziyad S. Alomari ${ }^{a^{*}}$
}

\begin{tabular}{l} 
a Jadara University, Jordan \\
\hline C H R O N I C L E \\
\hline Article history: \\
Received: August 182019 \\
Received in revised format: Au- \\
gust 182019 \\
Accepted: September 19, 2019 \\
Available online: \\
September 19, 2019 \\
\hline Keywords: \\
Human Capital \\
Strategic Thinking \\
Strategic HRM \\
\hline
\end{tabular}

\begin{abstract}
A B S T R A C T
The literature suggests that strategic thinking is a single learning loop based on a number of strategic theories. Therefore, this study examines the relationship between strategic thinking and strategic human resource management (HRM) in banking industry of Jordan. We also look at whether human capital can be used to boost the relationship between strategic thinking and strategic HRM. In order to achieve these objectives, the researcher conducts an explanatory, applied, and cross-sectional investigation where the instrument of this study is a questionnaire. The proposed study of this paper uses structural equation modeling to examine the hypotheses of the survey. The result shows that strategic thinking had a positive and significant effect on strategic HRM. Moreover, human capital has a positive and significant effect on strategic HRM. The implications of the results are discussed for human capital and the author concludes with the research agenda and recommendations on how future banks can effectively benefit from strategic thinking and human capital to enhance strategic HRM.
\end{abstract}

\section{Introduction}

C) 2020 by the authors; licensee Growing Science, Canada

Today, organizations are driven by competitiveness and competitive advantage. However, in order to achieve competitive advantage, organizations must strategically manage their resources which include human resources. Human Resource Management (HRM) has the capacity to provide competitive advantage and thus it is crucial for organization's strategic management. Wright et al. (2001) refers to dexterous employees in an organization as the organization's human capital pool. Recently, the intensity of competition between organizations has been increased, moreover the challenges increased particularly with globalization and technological revolution. Among the major current challenges that face organizations is their ability to cope with fluctuations, particularly in developing countries characterized by the fragility of their economies, in addition to their inability to effectively cope with and adopt rapid change. Human element is considered as one of the most important elements in productivity in the organization, therefore, senior management and line mangers have started to think strategically for developing organization performance in order to face the challenges and continue in the market. Knowledge management is the basic strategic thinking when knowledge is seen like the axis process for various function areas in the organization, managers use strategic thinking in order to find out the best way of making decisions. Strategic thinking's purpose and desired outcomes have been noted as the development of novel strategy (Heracleous, 1998). To that end, strategic thinking is described by its characteristics as operations thinking. The undertaken problem has become necessary for the administration to a sophisticated performance. Additionally, adopted modern strategies in public and private organizations meet challenges causing by globalization and the revolution of technology (Aghazadeh, 1999). According to Kaufman et al. (2003), world is in daily change with quality of life which lead to the need of new rules and procedures for working and living, the old paradigms do not work anymore but we still cling to them to solve current problems. Therefore, we need strategic thinking using societal added as a guide in solving today's problems and to choose the right decisions. Strategic thinking uses

* Corresponding author.

E-mail address: ziyadalomari@yahoo.com (Z. S. Alomari) 
tools to help managers implement the future plans and recruit the opportunities to enhance the organizational performance (Noubar, et al, 2014; Zabriskie \& Huellmantel, 1991). The commercial banks sector is considered as one of the most important business sectors in Jordan, as a result of the development of globalization and technology and the increasing of competitors, the Jordanian commercial banks sector faces many challenges especially with the conflicts and non-stable situation in countries around Jordan. Because of that, many skilled and expert mangers specialized in strategic human recourses management in commercial banks have migrated outside. Therefore, managers started to think seriously in developing the strategies of human recourses management in order to find the solutions that meet the challenges of the globalization and competitors. Therefore, this study will highlight the importance of the impact of strategic thinking on strategic human recourse management in the Jordanian commercial banks.

\subsection{Research Questions}

Q1: What is the impact of strategic thinking on strategic HRM?

Q2: What is the impact of strategic thinking on selection and recruitment?

Q3: What is the impact of strategic thinking on development and training?

Q4: What is the impact of strategic thinking on compensation?

Q5: does the known advantages of human capital augment the relationship between strategic thinking and strategic HRM?

Q6: is there any moderating effect of human capital significant across all dimensions of strategic human resource management? And what will this imply for firms managers?

\subsection{Significance of Study}

The importance of this study is derived from the importance of strategic thinking and strategic human resource management due to the fact that the employees are the important entity in the business sector. In addition to that, the banking sector is considered as one of the most important business sectors in the world. The strategic thinking and human recourse management plays an important role in improving the performance in banking sector, therefore, this research intended to explore how strategic thinking can improve the strategic human resources management. Finally, this research aims to cover the lack of literature reviews related to the effect of strategic thinking on the human resource management.

\subsection{Aim of Study}

This paper aims to identify the level of applying strategic thinking in Jordanian banking sector. Moreover, the level of applying strategic HRM will be identified in Jordanian banking sector. The impact of strategic thinking and its dimensions will also be examined for the selection and recruitment, development and training, compensations, and performance evaluation. Additionally, this study will investigate the impact of demographic variables on strategic thinking and strategic HRM.

\subsection{Research Model}

The proposed model of this study with three independent variables represents strategic thinking and its dimensions, the model includes dependent variable Strategic HRM as shown in Fig. 1. The model of this research is also designed according to Khalili et al. (2015); Heracleous (1998); Noubar et al. (2014) and Porter (1987).

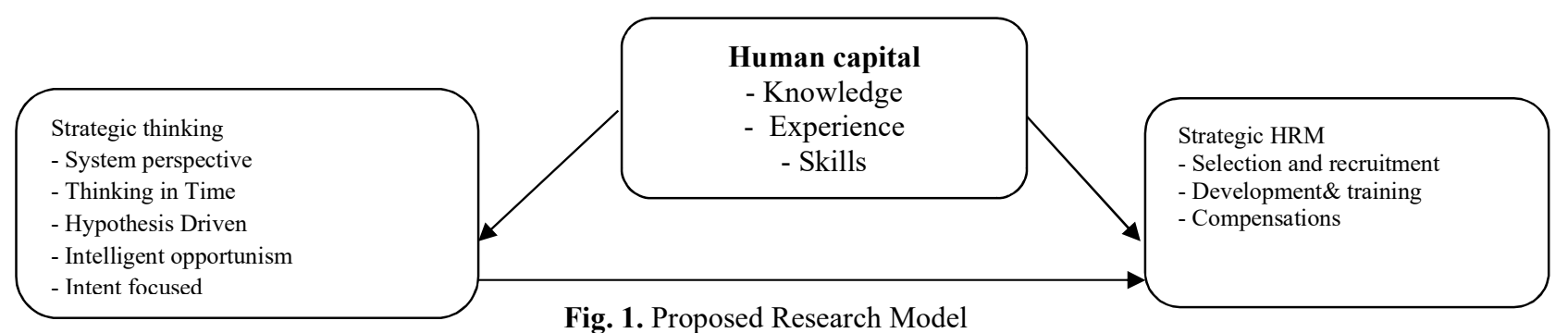

Fig. 1. Proposed Research Model

\subsection{Hypothesis}

The following hypotheses will guide the researcher in making presumptions and deep analysis.

H1: Human capital moderates the relationship between system perspective and Strategic HRM, such that the effect of system perspective on Strategic HRM would be greater when human capital is higher.

$\mathbf{H}_{2}$ : Human capital moderates the relationship between intent focused and Strategic HRM, such that the effect of intent focused on Strategic HRM would be greater when human capital is higher.

H3: Human capital moderates the relationship between intelligent opportunism and Strategic HRM, such that the effect of intelligent opportunism on Strategic HRM would be greater when human capital is higher.

H4: Human capital moderates the relationship between thinking in time and Strategic HRM, such that the effect of thinking in time on Strategic HRM would be greater when human capital is higher. 
Hs: Human capital moderates the relationship between Hypothesis driven and Strategic HRM, such that the effect of Hypothesis driven on Strategic HRM would be greater when human capital is higher.

\section{Literature review}

\subsection{Strategic thinking}

Although strategic thinking has long been used in our daily lives and in our businesses, but as academic concept, it has been researched recently. Researchers began to realize, define, and find elements dimensions of this type of strategies only within last two decades. There are definitions provided by scholars who are interested in this kind of strategies. The researcher in this study will highlight on the most important studies related to this kind of strategies and the most popular detentions of strategic thinking. Mintzberg (1994) developed the concept of strategic thinking in an academic framework and identified goals and dimensions to set its borders with the other terms. It has indicated that strategic thinking is a special way of thinking, is interested in addressing the insight, resulting in an integrated perspective of the organization, through a synthetic process resulting from the hiring of good intuition and creativity in the formulation of strategic directions. Strategic thinking is synthetic, divergent, creative thought process which aims to discover imaginative strategies which can re-write the rules of competitive game and envision potential futures significantly differently from the present (Heracleous, 1998). Kaufman et al. (2003) defines strategic thinking as a way in how individuals in an organization think, view, assess and create the future. Tavakoli and Lawton (2005) defined it as a cognitive process whereby an individual involves the past with the present in order to contemplate the future development of the organization. Strategic thinking for any successful business depends on the investigation of the clients 'voice, as much as on the qualifications and experiences of the employees. This yields the examining of each point in any various roles, also understanding the requirements of the clients and being sure that all these are linked to clearly define strategic duties (Heracleous, 1998). Comparing the strategic thinking with a) strategic planning, and b) operational planning, the obtained answers are:

- Strategic thinking means the answer of "What" and "Why".

- Strategic planning is the answer of "How" and "When" at all higher levels of planning.

- Operational planning is the exact details of the "How" and "When".

\subsection{Importance of Strategic Thinking}

The goal of strategic thinking is to produce a strategy that is a coherent, unifying, integrative framework for decisions especially about direction of the business enterprise and resource utilization (Kamangar et al., 2013). To complete it, strategic thinking employs central and additional information, qualitative synthesis of thoughts and perceptions. It is aware, specific, and practical and becomes aggressive domain for corporate proper advantages. Strategy is just an important result of an applicable proper considering process. Tregoe et al. (1988) discussed the partnership between strategy and procedure within their work, Top Management Strategy: What it is and How to make it Work as shown in Fig. 1.

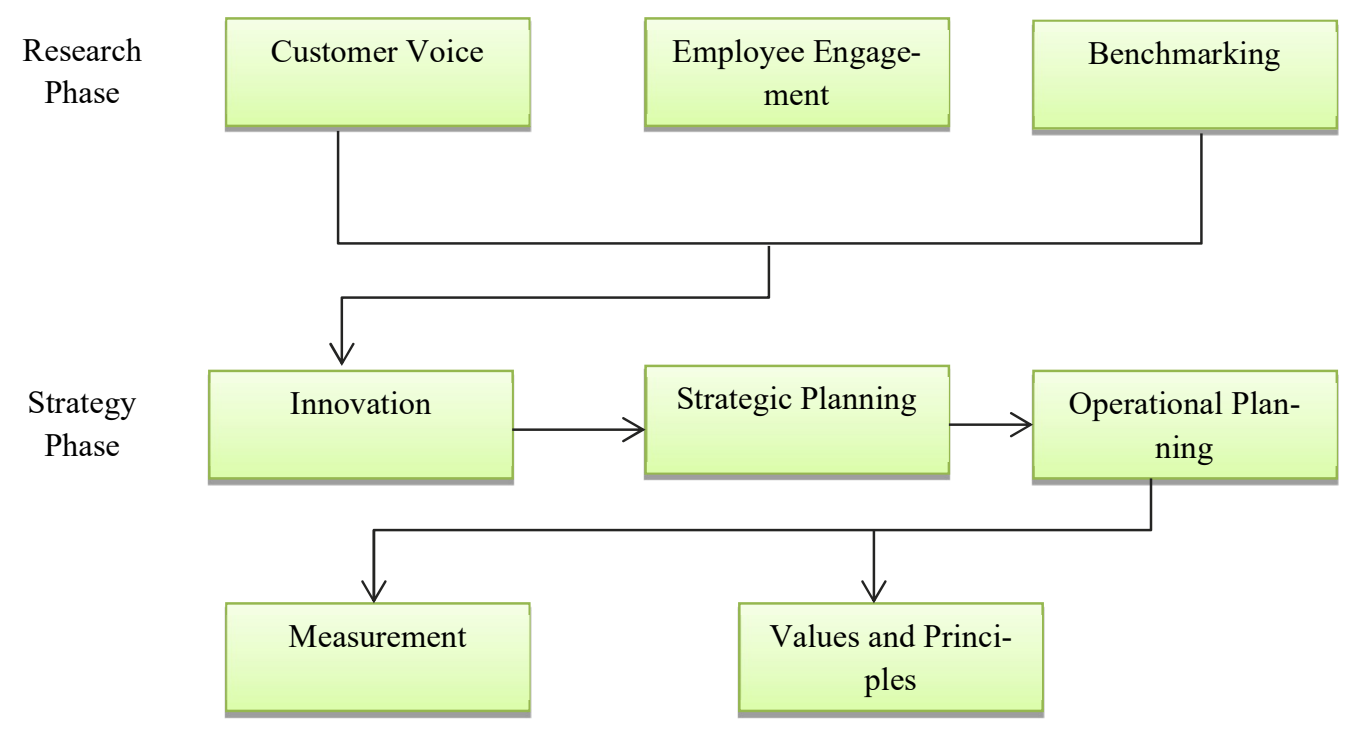

Fig. 2. Strategic Thinking

Strategic thinking can be a combination involving Creativity, Strategic Planning, as well as Operational Planning. This process commences with Creativity. Attempting to make the best long term and finding the necessary strategies to attain these goals; 
Creativity allows to relocate out of doors own rut directly into the choices involving outperforming buyer, business prerequisites, and expectations (Salamzadeh et al., 2015). New developments will be subsequently articulated directly into several strategies. That is an element of the entire organizing process. Nevertheless, throughout organizing contemplating, most of us include things like the requirements of our own buyers, the business as well as our own workers from the process. Many of us incorporate Benchmarking to ensure sector greatest methods will be involved within our eye sight in the future (Deiss \& Petrowski, 2009).

\subsection{Strategic thinking's elements}

System perspective: strategic thinking is based on the establishment of a system perspective and strategic thinkers have a mental model of the complete end-to-end arrangement of quality creation, and comprehends the bury conditions inside it. This mental model of "how the world works" must join a comprehension of both the outside and inside connection of the organizations.

Hypothesis driven: The company gets a much-focused analysis and does not need to do an exhaustive search for all possible solutions. Hypothesis driven is associated with scientific method and selects the most promising hypothetical in the process and seeks to confirm or refuse it. The scientific method accommodates both creative and analytical thinking sequentially in its use of iterative cycles of hypothesis generating and testing. Hypothesis generation asks the creative question what if. .?".

Thinking in time: according to Neustadt and May (1986), thinking in time has three components; first one is recognition that future has no place to come from, but the past predictive value. Second component is recognition that what matters for the future in the present is departure from the past, alterations, changes which prospectively or actually divert familiar flows from accustomed channels. Final component is continuous comparison, an almost contact oscillation from the present to future to past and back, heedful of prospective change, concerned to expedite, limit, guide, counter, or accept it as the fruits of such comparison suggest. Thinking in time, in this view, uses both an institution's memory and its broad historical context to think well about creating its future. This requires capability both for choosing and using appropriate analogies from its own and other's histories, and for recognizing patterns in these events.

Creativity gives better art, and far from destroying the artist, it can improve an artist's life or a scientist's life, or a businessperson's life (Kaufman et al., 2003). Creativity is the first foundation of strategic thinking, in other words, it represents the first step towards strategic thinking and success in achieving competitive advantage. Creativity is generally defined as the ability or power to create, to invest with a new form, to produce through imaginative skill and to make or bring into something new. Critical thinking is both a deliberate meta-cognitive (thinking about thinking) and cognitive (thinking) act whereby a person reflects on quality of reasoning process simultaneously while reasoning to a conclusion. The thinker has two equally important goals: improving the way: she or he reasons and coming to a correct solution (Moor, 2010). Analytical ability is the ability to analyze complex material and solve problems (Segal, et al., 1985), and as stated by Waters(2011) Analytical ability is to uncover how well the candidate can gather information and extract relevant data whether reaching conclusions, solving problems or making valid decisions, a productive employee needs strong analytical skills.

\subsection{Strategic HRM}

Most organizations in the world are seeking to achieve competitive advantage and struggle for survival and continuity in order to achieve the profit at the end. Recently, the intensity of competition between organizations has been increased, moreover the challenges increased especially after globalization and technological revolution. Among the major challenges currently facing organizations is their ability to cope with fluctuations, particularly in developing countries which is characterized by the fragility of their economies, and the inability of organizations to effectively cope and adopt with the rapid changes. The human element is considered as one of the most important elements in productivity in the organization, therefore, senior management and mangers have started to think strategically in selection and development of human resources in order to face the challenges and continue in the competition. Human resource management is the most important place in an organization and it is an approach for the implementation of company's strategies and achievement (Kucharčíková, et al., 2015). Strategic Human resources management working is to put the right people in the right place and increase the productivity and raise morale, reduce work-related accidents, which increases the importance of the strategic human resources management in companies (Wright \& McMahan, 2011). Organizations do not develop only from financial side. If a company is financially good it may not make the firm successful. But a good strategic human resource makes the company successful and growth to achieve on the organization. The development of the staff policies of the enterprises will provide a great advantage to the company for the competitive environment (Marimuthu, et al., 2009). All successful companies will have good human resources management, because it is working to increase the skills and values of the company (Souleh, 2014). Using the human resources management in a straight way provides the company with competitive advantage (Odhiambo, \& Waiganjo, 2014; Waiganjo et al., 2012). Using the only structure that cannot be imitated in companies is human capital (Becker, et al., 2012). 


\section{Methodology}

The objectives of this study are to explore the effect of both strategic thinking and human capital on strategic human resources management and to explore the potential moderating role played by human capital. The questionnaire contains four sections. The first section involves questions related to demographic characteristics of the respondent, including gender, education level, position, and experience. The second section includes 27 questions reflecting the level of strategic thinking practices in the respondent company. The strategic thinking practice includes five sub-practices, including system perspective, thinking in time, hypothesis driven, intelligent opportunism and intent focused. The questions adopted from Khalili et al. (2015). The third section involves 12 questions assessing the human capital. This variable involves three sub-dimensions including Knowledge, Experience, and Skills. The questions adopted from Noubar et al. (2014). The last section contains 15 questions which reflects the level of strategic human resources management practices. This variable includes three sub-dimensions containing Selection and Recruitment and Selection, Development and Training, and Compensations. The questions adopted from Heracleous. The population of this study comprised all banks' employees working in Amman -Jordan. The respondents of this study consists of all functional employees in the banks. Using Random sample technique, the researchers self-administrated 403 questionnaires to the prospective respondents. The researchers received in total 350 questionnaires after several follow up procedures. Out of them, only 303 responses were valid for further analysis after removing responses with large missing data. The demographic characteristics of the sample are presented in Table 1. As shown in the table, the majority of the sample members are males, accounting for $82 \%$ of the sample. Most of the respondents also have either a Bachelor or Master degree, representing $51 \%$ and $47 \%$ of the sample members, respectively. With regard to the experience, about $10 \%$ of the respondents have an experience less than 10 years. Meanwhile, those respondents who have experience between 16 and 20 years and more than 20 years represent about $33 \%$ and $31 \%$ of the sample members, respectively. Moreover, about $24 \%$ of the sample members have experience between 11 and 15 years. Finally, about $52 \%$ of the sample members are normal employees. Meanwhile, respondents with job title managers and manager's assistance represent about $18 \%$ and $28 \%$ of the sample members, respectively. The descriptive statics of the demographic's variables show that the respondents have the sufficient knowledge to provide valid responses for this study.

Table 1

The demographic characteristics of the sample

\begin{tabular}{|c|c|c|c|}
\hline Variable & Details & Frequency & Percent \\
\hline \multirow[t]{2}{*}{ Gender } & Male & 249 & 82.5 \\
\hline & Female & 53 & 17.5 \\
\hline \multirow[t]{6}{*}{ Qualification } & Doctorate & 2 & .7 \\
\hline & Master & 142 & 47.0 \\
\hline & Bachelor & 155 & 51.3 \\
\hline & Others & 3 & 1.0 \\
\hline & Less than 5 & 3 & 1.0 \\
\hline & 6-10 & 27 & 8.9 \\
\hline \multirow[t]{4}{*}{ Experience } & $11-15$ & 74 & 24.5 \\
\hline & $16-20$ & 102 & 33.8 \\
\hline & More than 20 & 96 & 31.8 \\
\hline & Manager & 57 & 18.9 \\
\hline \multirow[t]{2}{*}{ Job description } & Assistant manager & 86 & 28.5 \\
\hline & Employee & 159 & 52.6 \\
\hline Total & & 302 & 100.0 \\
\hline
\end{tabular}

The descriptive statistics of the variables are shown in Table 2. It can be seen that the mean values range from 4.30 for Intent focused to 4.40 for Intelligence opportunism. These figures indicate high perceptions of employees toward Strategic thinking, Human Capital, and Strategic HRM.

Table 2

Descriptive statistics of the variables

\begin{tabular}{lll}
\hline Variable name & Mean & Standard Deviation \\
\hline Intent focused & 4.305689 & 0.390848 \\
Hypotheses driven & 4.379895 & 0.420367 \\
Thinking in time & 4.327433 & 0.432909 \\
Intelligence opportunism & 4.406606 & 0.40577 \\
Knowledge & 4.332891 & 0.408738 \\
Skills & 4.342969 & 0.389716 \\
Experience & 4.313841 & 0.407237 \\
Recruitment and Selection & 4.268962 & 0.408013 \\
Training and Development & 4.313426 & 0.408907 \\
Compensations & 4.347123 & 0.410734 \\
Strategic Thinking & 4.358157 & 0.404968 \\
Strategic HR & 4.348516 & 0.286703 \\
Human Capital & 4.34183 & 0.304043 \\
\hline
\end{tabular}


The researchers performed several data screening activities before estimating parameters on data and testing hypotheses. First, we made sure that there were no recording or coding errors in the data. Second, as indicated earlier, we removed all observations that contained missing data. Third, we examined for the normal distribution of the data. We estimated the Kurtosis and Skewness for each variable included in this study. The results indicated that all the variables expressed satisfactory values (+/- 2) (Hair et al., 2010) for both Kurtosis and Skewness except for one variable. To deal with this issue, we decided to use a nonparametric method of data analyses which will be discussed later. Finally, we checked for Multicollinearity issue by estimating Variance inflation factor (VIF).The results indicated that all variables show VIF values less than the threshold value 2 signifying that Multicollinearity is not an issue for this study (Hair et al., 2010). However, the data screening activities indicated that the data can be safely used for further analyses.

\subsection{Data analysis}

This study employed the Partial Least Square (PLS) to examine the hypotheses of this study. PLS is a nonparametric and Variance based approach for Structured Equation Modeling (Alsaad et al., 2017; Henseler et al., 2016). Our decision to use PLS is grounded on the following reasons. First, the data used in this study does not meet the normal distribution assumption as shown above. PLS does not assume the normal distribution of the data, making PLS the proper method for data analyses when the normality assumption is violated (Alsaad et al., 2018b; Hair et al., 2014a; Hair et al., 2011; Sekaran \& Bougie, 2016). Second, the main variables in this study are operationalized at a high level of abstraction which increases the complexity of the model. As suggested in the literature, PLS is highly recommended to deal with complex models (Alsaad et al., 2015; Becker et al., 2012). Finally, this study suggests a moderation effect which increases the complexity of the model and requires a large sample size to be successfully examined (Alsaad et al., 2018b; Hair et al., 2014b).

Table 3

The measurement model reliability and convergent validity

\begin{tabular}{|c|c|c|c|c|c|}
\hline Variable name & Item name & Loading & T value & Composite & AVE \\
\hline \multirow{4}{*}{ System perspective (SP) } & $\mathrm{X} 2$ & 0.676 & 9.9469 & \multirow[t]{4}{*}{0.8199} & \multirow[t]{4}{*}{0.5331} \\
\hline & $\mathrm{X} 3$ & 0.7571 & 11.7069 & & \\
\hline & $\mathrm{X} 4$ & 0.775 & 10.5636 & & \\
\hline & X5 & 0.7082 & 13.4825 & & \\
\hline \multirow{3}{*}{ Intent focused (IF) } & $\mathrm{X} 7$ & 0.7444 & 9.6875 & \multirow[t]{3}{*}{0.8081} & \multirow[t]{3}{*}{0.585} \\
\hline & $\mathrm{X} 8$ & 0.8314 & 15.7156 & & \\
\hline & X9 & 0.7139 & 15.9286 & & \\
\hline \multirow{4}{*}{ Hypotheses driven (HD) } & $\mathrm{X} 12$ & 0.7059 & 16.5874 & \multirow[t]{4}{*}{0.829} & \multirow[t]{4}{*}{0.5482} \\
\hline & $\mathrm{X} 13$ & 0.7471 & 8.3386 & & \\
\hline & $\mathrm{X} 15$ & 0.739 & 13.275 & & \\
\hline & $\mathrm{X} 16$ & 0.7682 & 11.7676 & & \\
\hline \multirow{3}{*}{ Thinking in time (TT) } & $\mathrm{X} 20$ & 0.722 & 15.4131 & \multirow[t]{3}{*}{0.8073} & \multirow[t]{3}{*}{0.5834} \\
\hline & $\mathrm{X} 21$ & 0.8151 & 18.3285 & & \\
\hline & $\mathrm{X} 22$ & 0.7514 & 12.5864 & & \\
\hline \multirow{4}{*}{ Intelligence opportunism (IP) } & $\mathrm{X} 23$ & 0.7464 & 15.1289 & \multirow[t]{4}{*}{0.8209} & \multirow[t]{4}{*}{0.5351} \\
\hline & $\mathrm{X} 24$ & 0.7471 & 12.3196 & & \\
\hline & $\mathrm{X} 25$ & 0.7778 & 13.6891 & & \\
\hline & $\mathrm{X} 27$ & 0.6483 & 10.8201 & & \\
\hline \multirow{4}{*}{ Knowledge (KN) } & $\mathrm{X} 28$ & 0.6536 & 12.4202 & \multirow[t]{4}{*}{0.8309} & \multirow[t]{4}{*}{0.5526} \\
\hline & X29 & 0.7987 & 22.5577 & & \\
\hline & $\mathrm{X} 30$ & 0.7743 & 19.8717 & & \\
\hline & $\mathrm{X} 31$ & 0.7387 & 23.1025 & & \\
\hline \multirow{4}{*}{ Skills (SK) } & $\mathrm{X} 32$ & 0.6871 & 20.1445 & \multirow[t]{4}{*}{0.8001} & \multirow[t]{4}{*}{0.5015} \\
\hline & X33 & 0.6884 & 19.632 & & \\
\hline & $\mathrm{X} 34$ & 0.7915 & 17.4146 & & \\
\hline & $\mathrm{X} 35$ & 0.6584 & 10.335 & & \\
\hline \multirow{4}{*}{ Experience (EX) } & $\mathrm{X} 36$ & 0.6346 & 11.3528 & \multirow[t]{4}{*}{0.8011} & \multirow[t]{4}{*}{0.5032} \\
\hline & X37 & 0.7191 & 18.5122 & & \\
\hline & $\mathrm{X} 38$ & 0.7879 & 16.8896 & & \\
\hline & X39 & 0.6871 & 8.5972 & & \\
\hline \multirow{3}{*}{ Recruitment and Selection (RE) } & $\mathrm{X} 40$ & 0.7594 & 12.8538 & \multirow[t]{3}{*}{0.7883} & 0.5542 \\
\hline & $\mathrm{X} 41$ & 0.7657 & 12.0185 & & \\
\hline & $\mathrm{X} 42$ & 0.7069 & 12.6481 & & \\
\hline & $\mathrm{X} 46$ & 0.7412 & 12.5531 & 0.8099 & 0.587 \\
\hline Training and Development (TR) & $\mathrm{X} 47$ & 0.7664 & 14.6494 & & \\
\hline & $\mathrm{X} 48$ & 0.7901 & 18.7743 & & \\
\hline & $\mathrm{X} 50$ & 0.6828 & 13.8888 & 0.8025 & 0.5055 \\
\hline & $\mathrm{X} 51$ & 0.7759 & 11.136 & & \\
\hline Compensations (CO) & X52 & 0.7454 & 11.7792 & & \\
\hline & X53 & 0.6312 & 11.7195 & & \\
\hline
\end{tabular}


Unlike other approaches for data analysis, PLS imposes the least requirement for sample size. Having these attributes for PLS in mind PLS would be the best choice to test the suggested hypotheses in this study. We adopted the two steps approach to analyses our data using PLS. In the first step, we assessed the measurement model. We assessed the structure model and tested the hypotheses in the second step. The measurement model is assessed by estimating the internal consistency, the convergent validity, and the discriminate validity. Composite reliability was employed to assess the internal consistency of the proposed measures (Sarstedt et al., 2014). Table 3 presents the values of composite reliability for each first ordered construct used in the model. All the composite reliability values ranged from 0.78 for Recruitment and Selection to 0.83 for Knowledge which is well above the threshold value 0.70 and imply that the measurement model can be considered reliable. Next, convergent validity was examined. Convergent validity shows how well the items share variance in demonstrating the construct. An important condition to ensure convergent validity is confirming unidimensionality which is evaluated by estimating items loading and their significance level. Item loading should be 0.7 and above. In some cases, 0.6 is acceptable if it does not affect the average variance extracted (AVE) (Hair et al., 2011). Having these in mind, we removed all the items whose load was less than 0.7 and affect the AVE. The remaining items, their loadings, and their significance level are presented in Table 3. As shown in the table, the $t$ values are above 1.96 indicating that all the items load significantly on their postulated construct. Convergent validity was also evaluated by inspecting average variance extracted (AVE). Following Hair et al. (2011), convergent validity is achieved when each construct's AVE exceeds 0.50. As shown in Table 3, the AVEs of the measurement model ranged from 0.505 for Compensations to 0.58 for Intent focused. These figures demonstrate a satisfactory convergent validity. Discriminant validity was inspected next. It denotes to the extent to which the items of two variables are empirically separated. We employed two measures to assess the discriminant validity which are Heterotrait-Monotrait Ratio of Correlations (HTMT) and items cross loading. HTMT is a new authentic and reliable measure to assess the discriminant validity and it is more accurate than other criterions(Henseler et al., 2016). According to the rule of thumb, discriminant validity is recognized when the HTMT value between a particular pair of variables is below 0.90 (Henseler et al., 2016). Table 4 shows that all the HTMT values are well below 0.90 .

Table 4

Discriminant validity- Heterotrait-Monotrait Ratio of Correlations

\begin{tabular}{|c|c|c|c|c|c|c|c|c|c|c|c|}
\hline Construct & (SP) & (IF) & (HD) & (TT) & (IP) & $(\mathrm{KN})$ & (SK) & (EX) & (RE) & (TR) & (CO) \\
\hline \multicolumn{12}{|l|}{ SP } \\
\hline IF & 0.5133 & & & & & & & & & & \\
\hline HD & 0.4826 & 0.4394 & & & & & & & & & \\
\hline TT & 0.4824 & 0.5172 & 0.5343 & & & & & & & & \\
\hline IP & 0.3242 & 0.5267 & 0.4423 & 0.8028 & & & & & & & \\
\hline KN & 0.4128 & 0.4901 & 0.4099 & 0.6702 & 0.5547 & & & & & & \\
\hline SK & 0.3844 & 0.4163 & 0.4039 & 0.5035 & 0.5218 & 0.7176 & & & & & \\
\hline EX & 0.289 & 0.4678 & 0.3682 & 0.5426 & 0.5813 & 0.4449 & 0.5373 & & & & \\
\hline RE & 0.3064 & 0.457 & 0.3137 & 0.4876 & 0.4716 & 0.4432 & 0.427 & 0.7985 & & & \\
\hline TR & 0.2997 & 0.4695 & 0.3301 & 0.4491 & 0.3806 & 0.4435 & 0.3612 & 0.522 & 0.5159 & & \\
\hline $\mathrm{CO}$ & 0.458 & 0.429 & 0.253 & 0.4178 & 0.3438 & 0.1932 & 0.2639 & 0.4372 & 0.4596 & 0.5462 & \\
\hline
\end{tabular}

In the second method, the cross-loading method, we compared the items loadings across the variables. Item loading should be higher on their postulated construct(Alsaad et al., 2018a; Elrehail et al., 2018; Hair et al., 2011). Results in Table 5 exhibit that the loading of all the items is higher at its postulated construct than other constructs in the model. Both methods presented above demonstrate that all the constructs are discriminately valid.

Having in mind that the measurement model is both valid and reliable; the next step is to evaluate the structure model and to test the suggested hypotheses. Since the suggested model proposes Human capital as a moderator, we tested two structure models wherein the first is intended to examine the effect of Strategic thinking and Human capital on Strategic $\mathrm{HRM}_{(\mathrm{H}} \mathrm{H}_{1}$ and $\mathrm{H}_{2}$ ) and the second model is intended to examine the moderating role played by Human Capital on the relationship between Strategic thinking and Strategic HR. We assessed both models as the following. First, for each influencing path, we assessed the path coefficient and their significance level. Second, we computed the coefficient of determination $\left(\mathrm{R}^{2}\right)$ of the dependent variable to assess the predicted power of the model. The results of the first model are depicted in Fig. 3 and presented in Table 6. The results indicate that the path coefficient of Strategic Thinking is 0.337 and significant at $\mathrm{p}<0.001$, suggesting that Strategic Thinking has a positive and significant effect on strategic HRM. This provides a strong support for $\mathrm{H}_{1}$. Similarly, the path coefficient of Human Capital is 0.273 and significant at $p<0.001$, suggesting that Human Capital has a positive and significant effect on strategic HRM. These figures provide sufficient evidence to support $\mathrm{H}_{2}$. Both Strategic thinking and Human capital jointly explain about $30 \%$ of the variance $\left(\mathrm{R}^{2}=29.9 \%\right)$ in Strategic HRM practices. With regard to the second model which accounted for the moderating role of Human Capital, we created an interaction latent variable which is a product of Human Capital $\times$ Strategic Thinking. Then, we regressed the resulted interaction latent variable against Strategic HRM with a presence of both Human Capital and Strategic Thinking. The results are presented in Table 7. The results indicate that the path coefficient of the interaction latent variable is -0.035 with a p-value $>0.05$, suggesting that Human Capital does not moderate the role of strategic thinking. Thus, we decide to reject $\mathrm{H}_{3}$. Moreover, the coefficient of determination of the second 
572

model $\left(\mathrm{R}^{2}=30 \%\right)$ does not change as compared with the first model, indicating that the moderating role of Human Capital does not contribute to explaining the Strategic HR.

Table 5

Discriminant validity- items cross loading

\begin{tabular}{|c|c|c|c|c|c|c|c|c|c|c|c|}
\hline Items & SP & IF & HD & TT & IP & $\mathbf{K N}$ & SK & EX & RE & TR & $\mathrm{CO}$ \\
\hline $\mathrm{X} 2$ & 0.6896 & 0.2789 & 0.1894 & 0.3277 & 0.1569 & 0.2359 & 0.2176 & 0.106 & 0.1295 & 0.2064 & 0.1988 \\
\hline X3 & 0.7465 & 0.2779 & 0.2259 & 0.2503 & 0.1498 & 0.2441 & 0.1944 & 0.194 & 0.1534 & 0.1539 & 0.2565 \\
\hline X4 & 0.7497 & 0.1865 & 0.2615 & 0.1925 & 0.131 & 0.1749 & 0.16 & 0.1304 & 0.1181 & 0.1323 & 0.2395 \\
\hline X5 & 0.7303 & 0.297 & 0.3423 & 0.1938 & 0.2396 & 0.2038 & 0.1963 & 0.1945 & 0.1802 & 0.1025 & 0.2255 \\
\hline$\times 7$ & 0.1661 & 0.6925 & 0.2245 & 0.1539 & 0.2369 & 0.2548 & 0.2035 & 0.1968 & 0.2404 & 0.1658 & 0.1171 \\
\hline X8 & 0.2999 & 0.8223 & 0.2132 & 0.2672 & 0.3048 & 0.2865 & 0.2533 & 0.2392 & 0.257 & 0.3136 & 0.2729 \\
\hline X9 & 0.3342 & 0.7689 & 0.2784 & 0.3353 & 0.2751 & 0.2181 & 0.1624 & 0.2879 & 0.1583 & 0.225 & 0.2602 \\
\hline X12 & 0.3607 & 0.2798 & 0.74 & 0.3443 & 0.2565 & 0.2598 & 0.2335 & 0.1987 & 0.2379 & 0.2191 & 0.2698 \\
\hline $\mathrm{X} 13$ & 0.2612 & 0.0768 & 0.7106 & 0.1908 & 0.1479 & 0.1626 & 0.1692 & 0.1322 & 0.0544 & 0.0649 & 0.0666 \\
\hline X15 & 0.2301 & 0.2377 & 0.7378 & 0.2659 & 0.2755 & 0.2208 & 0.2194 & 0.3051 & 0.2043 & 0.206 & 0.1291 \\
\hline X16 & 0.1808 & 0.2956 & 0.7667 & 0.2792 & 0.2671 & 0.2397 & 0.2167 & 0.1725 & 0.1224 & 0.1772 & 0.0588 \\
\hline $\mathbf{X} 20$ & 0.1986 & 0.2965 & 0.3224 & 0.7326 & 0.3815 & 0.317 & 0.2901 & 0.3017 & 0.2733 & 0.2837 & 0.2189 \\
\hline X21 & 0.3712 & 0.2328 & 0.3005 & 0.8168 & 0.4057 & 0.3913 & 0.2794 & 0.2607 & 0.2018 & 0.2186 & 0.2397 \\
\hline X22 & 0.173 & 0.2556 & 0.2307 & 0.7388 & 0.4586 & 0.3319 & 0.1898 & 0.2692 & 0.2164 & 0.1657 & 0.1703 \\
\hline$\times 23$ & 0.2093 & 0.3121 & 0.2913 & 0.4666 & 0.7661 & 0.2633 & 0.2266 & 0.3102 & 0.2045 & 0.1217 & 0.1956 \\
\hline X24 & 0.1214 & 0.2312 & 0.2569 & 0.3266 & 0.7318 & 0.2491 & 0.2338 & 0.317 & 0.2184 & 0.2773 & 0.1841 \\
\hline X25 & 0.2041 & 0.2238 & 0.2245 & 0.3711 & 0.7656 & 0.273 & 0.2587 & 0.3252 & 0.2197 & 0.1797 & 0.192 \\
\hline$\times 27$ & 0.1456 & 0.2768 & 0.1745 & 0.4105 & 0.6553 & 0.3679 & 0.3289 & 0.2486 & 0.2578 & 0.1702 & 0.1371 \\
\hline X28 & 0.2463 & 0.2928 & 0.2101 & 0.3628 & 0.3124 & 0.6444 & 0.3358 & 0.1835 & 0.1935 & 0.197 & 0.0866 \\
\hline X29 & 0.1799 & 0.2113 & 0.2372 & 0.3127 & 0.2863 & 0.7901 & 0.3638 & 0.2452 & 0.1512 & 0.2623 & 0.0573 \\
\hline X30 & 0.1815 & 0.2105 & 0.1725 & 0.3566 & 0.3062 & 0.7723 & 0.4058 & 0.2233 & 0.2738 & 0.2116 & 0.121 \\
\hline X31 & 0.2732 & 0.2725 & 0.2806 & 0.33 & 0.2666 & 0.757 & 0.4269 & 0.3148 & 0.2515 & 0.2399 & 0.1402 \\
\hline X32 & 0.1829 & 0.1689 & 0.1885 & 0.2441 & 0.2693 & 0.4656 & 0.7234 & 0.2514 & 0.1819 & 0.1987 & 0.1465 \\
\hline X33 & 0.1917 & 0.2013 & 0.2593 & 0.2874 & 0.2529 & 0.4642 & 0.7247 & 0.2644 & 0.2086 & 0.1872 & 0.1087 \\
\hline X34 & 0.1977 & 0.1783 & 0.1715 & 0.1585 & 0.2313 & 0.3008 & 0.7504 & 0.1981 & 0.138 & 0.0836 & 0.0736 \\
\hline X35 & 0.176 & 0.2168 & 0.1854 & 0.2448 & 0.2492 & 0.1851 & 0.6214 & 0.3288 & 0.2303 & 0.1972 & 0.1721 \\
\hline X36 & 0.2646 & 0.2466 & 0.27 & 0.2747 & 0.3375 & 0.2439 & 0.2543 & 0.6664 & 0.3053 & 0.2119 & 0.1866 \\
\hline X37 & 0.2173 & 0.2783 & 0.2667 & 0.3058 & 0.3352 & 0.309 & 0.3456 & 0.7701 & 0.3193 & 0.2572 & 0.235 \\
\hline X38 & 0.0834 & 0.2235 & 0.1567 & 0.2468 & 0.2953 & 0.2389 & 0.2273 & 0.7619 & 0.3821 & 0.2948 & 0.2098 \\
\hline X39 & 0.003 & 0.1303 & 0.0469 & 0.1746 & 0.1648 & 0.0958 & 0.1775 & 0.6182 & 0.4205 & 0.2093 & 0.2055 \\
\hline X40 & 0.127 & 0.1523 & 0.1545 & 0.2215 & 0.1999 & 0.2144 & 0.1849 & 0.3938 & 0.7353 & 0.1916 & 0.2589 \\
\hline X41 & 0.1829 & 0.2103 & 0.0953 & 0.2208 & 0.2273 & 0.1984 & 0.2567 & 0.3427 & 0.7516 & 0.2286 & 0.221 \\
\hline X42 & 0.1392 & 0.2588 & 0.2338 & 0.2276 & 0.2519 & 0.2412 & 0.1571 & 0.3621 & 0.7444 & 0.3024 & 0.1784 \\
\hline X46 & 0.1973 & 0.2605 & 0.2362 & 0.1718 & 0.1927 & 0.2158 & 0.2156 & 0.2376 & 0.2539 & 0.7591 & 0.2878 \\
\hline X47 & 0.1238 & 0.1648 & 0.1749 & 0.1954 & 0.2099 & 0.1988 & 0.1931 & 0.2671 & 0.2044 & 0.7383 & 0.2235 \\
\hline X48 & 0.1423 & 0.2842 & 0.1302 & 0.2979 & 0.178 & 0.2861 & 0.14 & 0.29 & 0.2866 & 0.7985 & 0.3263 \\
\hline $\begin{array}{r}\mathbf{X} 50 \\
\end{array}$ & 0.202 & 0.1915 & 0.1054 & 0.2456 & 0.3079 & 0.1533 & 0.1758 & 0.2421 & 0.2189 & 0.2721 & 0.7068 \\
\hline X51 & 0.2431 & 0.1708 & 0.1365 & 0.2363 & 0.1092 & 0.072 & 0.1293 & 0.1862 & 0.159 & 0.1839 & 0.7424 \\
\hline X52 & 0.2132 & 0.1904 & 0.1096 & 0.1755 & 0.1417 & 0.1093 & 0.1301 & 0.1821 & 0.1637 & 0.2457 & 0.7176 \\
\hline X53 & 0.2366 & 0.2756 & 0.1776 & 0.1243 & 0.1172 & 0.0516 & 0.0606 & 0.2201 & 0.278 & 0.3314 & 0.6696 \\
\hline
\end{tabular}

Table 6

The results of the first model using PLS bootstrapping procedures

\begin{tabular}{|c|c|c|c|c|c|}
\hline \multirow[t]{2}{*}{ Effect } & \multirow[t]{2}{*}{ Path coefficient } & \multicolumn{4}{|c|}{ Standard bootstrap results } \\
\hline & & Standard error & t-value & p-value (2-sided) & p-value (1-sided) \\
\hline Strategic Thinking $\rightarrow$ Strategic HR & 0.3368 & 0.0757 & 4.4501 & 0.0000 & 0.000 \\
\hline Human Capital $\rightarrow$ Strategic HR & 0.2728 & 0.076 & 3.5889 & 0.0003 & 0.0002 \\
\hline
\end{tabular}

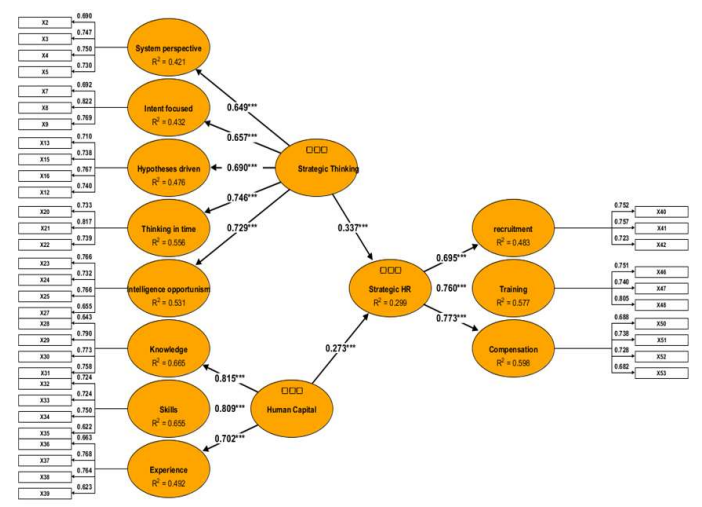

Fig. 3. The results of the first model using PLS bootstrapping procedures 
Table 7

The results of the first model using PLS bootstrapping procedures

\begin{tabular}{|c|c|c|c|c|c|c|}
\hline \multirow[t]{2}{*}{ Effect } & \multirow{2}{*}{$\begin{array}{c}\text { Path } \\
\text { coefficient }\end{array}$} & \multicolumn{5}{|c|}{ Standard bootstrap results } \\
\hline & & Mean value & Standard error & t-value & p-value (2-sided) & p-value (1-sided) \\
\hline Strategic Thinking $\rightarrow$ Strategic HR & 0.3262 & 0.3281 & 0.076 & 4.2942 & 0.000 & 0.0000 \\
\hline Human Capital $\rightarrow$ Strategic HR & 0.2729 & 0.2721 & 0.0762 & 3.5802 & 0.0004 & 0.0002 \\
\hline $\mathrm{HC}^{*} \mathrm{ST} \rightarrow$ Strategic HR & -0.035 & -0.035 & 0.0486 & -0.7199 & 0.4717 & 0.2359 \\
\hline
\end{tabular}

\section{Conclusion}

In summary, the objectives of this study are to explore the role of both Strategic thinking and human capital on Strategic HRM and to explore the moderating role played by human capital. The study used PLS to examine the suggested relationships due to its ability to deal with complex models and several data issues. Prior the data analysis we performed several data screening activities and assessed the measurement model reliability and validity. The results have indicated that the data and the measurement model met all conventional standards and quality criterions suggested in prior research. The results of the hypotheses testing (structure model assessment) provided support for $\mathrm{H}_{1}$ and $\mathrm{H}_{2}$ which suggest that as Strategic thinking and Human Capital increase, Strategic HRM increases too. Contrary to our expectation, the moderating role of Human Capital was less pronounced and thus $\mathrm{H}_{3}$ was rejected. Previous findings contribute to administrative literature in several ways. Studying the factors that influence organizational performance by combining macro-level and unit-level human capital is a very important answer that strategists can help plan. A pilot study with bank staff in Jordan adds to the formation of strategic thinking indicators and human capital. The results also show that the rigorous interrelationships of processes that determine the positive organizational results derived from strategic thinking and human capital in the workplace should pay great attention to how strategic thinking elements and human capital interact. Managers should also ensure that employees are more likely to engage in their business and demonstrate effective performance. Instead, seminars and workshops can be organized as a form of feedback mechanism to harvest important and important information from workers.

\section{References}

Aghazadeh, S. M. (1999). Human resource management: issues and challenges in the new millennium. Management Research News, 22(12), 19-32.

Alsaad, A. K., Yousif, K. J., \& AlJedaiah, M. N. (2018a). Collaboration: The key to gain value from IT in supply chain. EuroMed Journal of Business, 13(2), 214-235.

Alsaad, A., Mohamad, R., \& Ismail, N. A. (2015). Perceived desirability and firm's intention to adopt business to business ECommerce: A test of second-order construct. Advanced Science Letters, 21(6), 2028-2032.

Alsaad, A., Mohamad, R., \& Ismail, N. A. (2017). The moderating role of trust in business to business electronic commerce (B2B EC) adoption. Computers in Human Behavior, 68, 157-169.

Alsaad, A., Mohamad, R., Taamneh, A., \& Ismail, N. A. (2018b). What drives global B2B e-commerce usage: an analysis of the effect of the complexity of trading system and competition pressure. Technology Analysis \& Strategic Management, 30(8), 980-992.

Becker, J.-M., Klein, K., \& Wetzels, M. (2012). Hierarchical latent variable models in PLS-SEM: Guidelines for using reflective-formative type models. Long Range Planning, 45(5-6), 359-394.

Deiss, K., \& Petrowski, M. J. (2009). ACRL 2009 strategic thinking guide for academic librarians in the new economy. Retrieved March, 25, 2009.

Elrehail, H., Lawrence, O., Alsaad, A., \& Alzghoul, A. (2018). The impact of transformational and authentic leadership on innovation in higher education: The contingent role of knowledge sharing. Telematics and Informatics, 35(1), 55-67.

Hair, J. F., Black, W. C., Babin, B. J., \& Anderson, R. E. (2010). Multivariate Data Analysis (7th editio). Upper Saddle River, NJ: Prentice Hall.

Hair, J. F., Hult, J. G. T. M., Ringle, C. M., \& Sarstedt, M. (2014a). A Primer on Partial Least Squares Structural Equation Modeling (PLS-SEM). SAGE Publications.

Hair, J. F. J., Sarstedt, M., Hopkins, L., \& Kuppelwieser, V. G. (2014b). Partial least squares structural equation modeling (PLS-SEM): An emerging tool in business research. European Business Review, 26(2), 106-121.

Hair, J. F., Ringle, C. M., \& Sarstedt, M. (2011). PLS-SEM : Indeed a Silver Bullet. Journal of Marketing Theory and Practice, $19(2), 139-151$.

Henseler, J., Hubona, G., \& Ray, P. A. (2016). Using PLS path modeling in new technology research: updated guidelines. Industrial Management \& Data Systems, 116(1), 2-20.

Heracleous, L. (1998). Strategic thinking or strategic planning. Long Range Planning, 31(3), 481-487.

Kamangar, F., Salavati, A., \& Karimi, M. Sh. (2013). Developing strategic thinking. Journal of Basic and Applied Scientific Research, 3(6), 546-552.

Kaufman, R., Oakley-Browne, H., Watkins, R., \& Leigh, D. (2003). Strategic planning for success: Aligning people, performance, and payoffs. John Wiley \& Sons. 
Khalili, K., Armani, M., Rahimi, H., Jamshidi, F., \& Jamshidi, Z. (2015). The role of strategic thinking in organizational performance: A case study of the municipality of Ilam. International Journal of Review in Life Sciences, 5(8), 56-62.

Kucharčíková, A., Tokarčíková, E., \& Blašková, M. (2015). Human capital management-Aspect of the human capital efficiency in University education. Procedia-Social and Behavioral Sciences, 177, 48-6

Liedtka, J. (1998). Linking strategic thinking with strategic planning. Strategy and Leadership, October(1), $120-129$.

Marimuthu, M., Arokiasamy, L., \& Ismail, M. (2009). Human capital development and its impact on firm performance: Evidence from developmental economics. The Journal of International Social Research, 2(8), 265-272.

Mintzberg, H. (1994). The fall and rise of strategic planning. Harvard business review, 72(1), 107-114.

Moor, D. T. (2010). Critical Thinking and Intelligence Analysis, National Defense Intelligence College, Washington, USA.

Neustadt, R., \& May, E. (1986). Thinking in time: the uses of history for policy makers.

Noubar, H., Orangi, M., \& Mejarshin, A. (2014). Effect of strategic thinking on organizational improvement (Iranian Mellat Bank). MAGNT Research Report, 2(4), 4045-4049.

Odhiambo, G. M., \& Waiganjo, E. (2014). Role of human capital management strategies on employee nobility in Kenya's public universities: A case study of Jomo Kenyatta University of Agriculture and Technology (JKUAT). International Journal of Business and Social Science, 5(6).

Porter, M. E. (1987). Corporate strategy: the state of strategic thinking. The Economist, 23(May), 21-22.

Salamzadeh, Y., Nejati, M., \& Heidaripourafshar, Y. (2015). An Investigation into the Impact of E-Customs on Stretching Strategic Thinking. Journal of Entrepreneurship, Business and Economics, 3(1), 105-139.

Saffar, N., \& Obeidat, A. (2020). The effect of total quality management practices on employee performance: The moderating role of knowledge sharing. Management Science Letters, 10(1), 77-90.

Sarstedt, M., Ringle, C. M., Smith, D., Reams, R., \& Hair, J. F. (2014). Partial least squares structural equation modeling (PLS-SEM): A useful tool for family business researchers. Journal of Family Business Strategy, 5(1), $105-115$.

Segal, J. W., Chipman, S. F., \& Glaser, R. (Eds.). (1985). Thinking and learning skills: Relating instruction to research (Vol. 1). Lawrence Erlbaum Associates.

Sekaran, U., \& Bougie, R. (2016). Research methods for business: A skill building approach. John Wiley \& Sons.

Souleh, S. (2014). The impact of Human Capital Management on the Innovativeness of Research Center: The case of Scientific Research Centers in Algeria. International Journal of Business and Management, 2(4), 80-96.

Tavakoli, I., \& Lawton, J. (2005). Strategic thinking and knowledge management. Handbook of business strategy, 6(1), 155160.

Tregoe, B. B., Tobia, P. M., \& Zimmerman, J. W. (1988). Strategy and resource allocation. The Bankerls Handbook, 142160.

Waters, D. E. (2011). Understanding strategic thinking and developing strategic thinkers. Joint Force Quarterly, 63(113).

Waiganjo, E. W., Mukulu, E., \& Kahiri, J. (2012). Relationship between strategic human resource management and firm performance of Kenya's corporate Organizations. International Journal of Humanities and Social Science, 2(10), 62-70.

Wright, P. M., \& McMahan, G. C. (2011). Exploring human capital: putting 'human'back into strategic human resource management. Human Resource Management Journal, 21(2), 93-104.

Zabriskie, N. B., \& Huellmantel, A. B. (1991). Developing strategic thinking in senior management. Long Range Planning, $24(6), 25-32$.

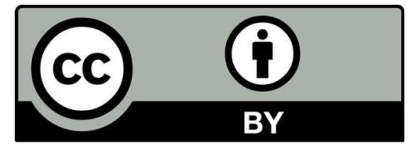

(C) 2020 by the authors; licensee Growing Science, Canada. This is an open access article distributed under the terms and conditions of the Creative Commons Attribution (CCBY) license (http://creativecommons.org/licenses/by/4.0/). 